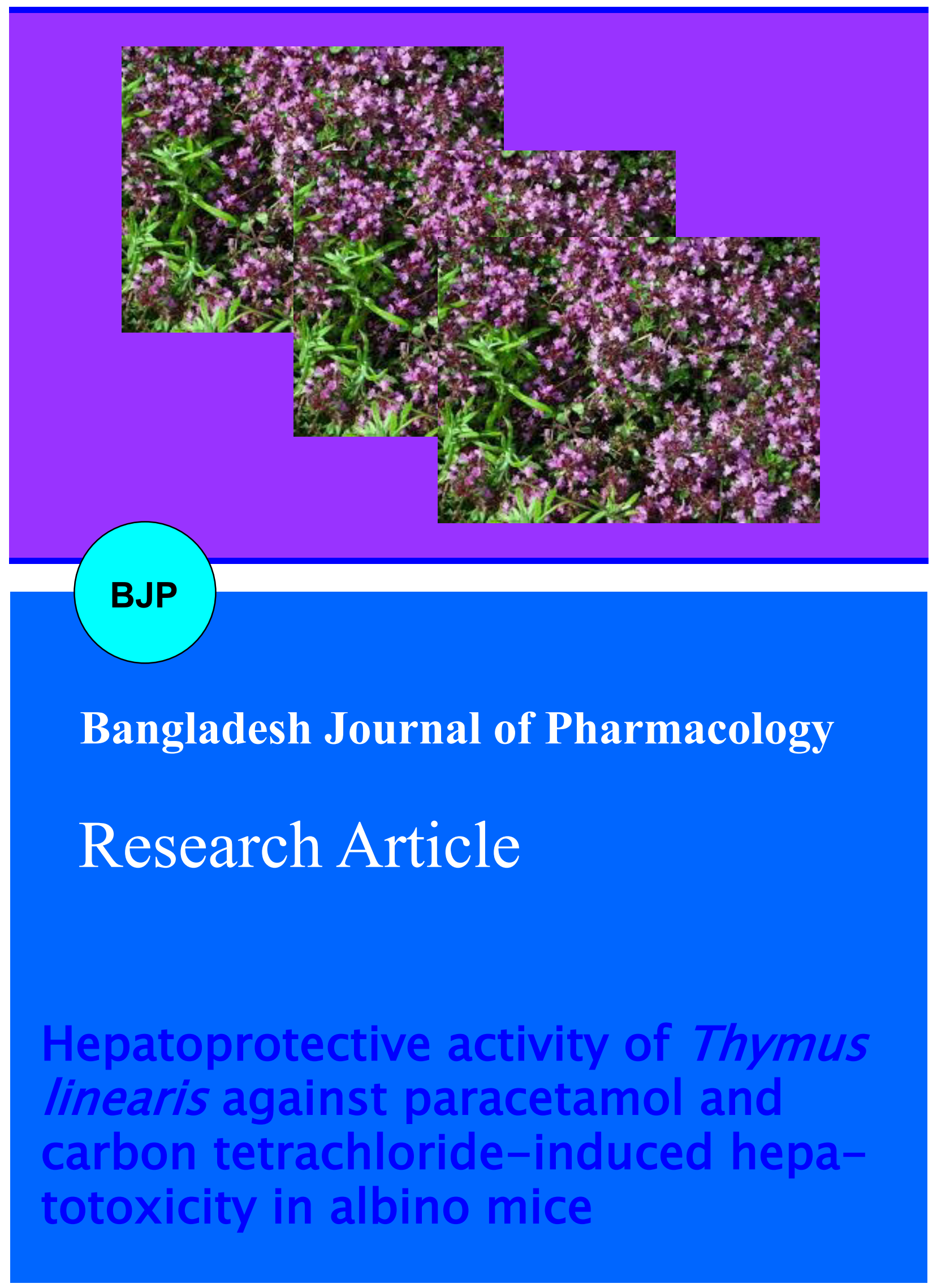




\title{
Hepatoprotective activity of Thymus linearis against paracetamol and carbon tetrachloride-induced hepatotoxicity in albino mice
}

\author{
Alamgeer ${ }^{1}$, Mehwish Nawaz ${ }^{1}$, Taseer Ahmad ${ }^{2}$, Muhammad Naveed Mushtaq ${ }^{1}$ and \\ Asma Batool 1
}

${ }^{1}$ Faculty of Pharmacy, University of Sargodha, Sargodha, Pakistan; ${ }^{2}$ Shifa College of Pharmaceutical Sciences, Shifa Tameer-e-Millat University, Islamabad, Pakistan.

\begin{tabular}{|c|}
\hline Article Info \\
\hline 12 March 2014 \\
\hline 14 April 2014 \\
\hline Available Online: \\
\hline DOI: 10.3329/bjp.v9i2.18329 \\
\hline $\begin{array}{l}\text { Cite this article: } \\
\text { Alamgeer, Nawaz M, Ahmad T, } \\
\text { Mushtaq MN, Batool A. Hepatopro- } \\
\text { tective activity of Thymus linearis } \\
\text { against paracetamol and carbon tetra- } \\
\text { chloride-induced hepatotoxicity in } \\
\text { albino mice. Bangladesh J Pharmacol. } \\
\text { 2014; 9: 230-34. }\end{array}$ \\
\hline
\end{tabular}

\begin{abstract}
In the present study, the hepatoprotective activity of aqueous and ether extracts of Thymus linearis (250 and $500 \mathrm{mg} / \mathrm{kg}$ orally) was evaluated against carbon tetrachloride- and paracetamol-induced hepatic damage in mice. Serum levels of alanine aminotransferase (ALT), aspartate aminotransferase (AST), and alkaline phosphatase (ALP) were assessed. Antioxidant activity of both the extracts was also determined using 1-1-diphenyl-2-picryl hydrazine (DPPH) scavenging method. The results indicated that both the extracts significantly produce a dose dependent reduction in serum levels of ALT, AST, and ALP when compared to carbon tetrachloride- and paracetamoltreated groups. The maximum effect in all the parameters was observed at a dose of $500 \mathrm{mg} / \mathrm{kg}$. The extracts also demonstrated a significant anti-oxidant activity. LD L $_{5}$ of both extracts was found to be 1050 and $900 \mathrm{mg} / \mathrm{kg}$ respectively. It is conceivable that the hepatoprotective activity of T. linearis might be due to the presence of certain pharmacologically active compounds.
\end{abstract}

\section{Introduction}

Many synthetic drugs are used to treat liver diseases but unfortunately these drugs have serious side effects (Guntupalli et al., 2006). The role of traditional medicines in solving health problems is valuable globally. This is even more impressive considering the fact that about $80 \%$ of people living in less developed countries rely exclusively on traditional medicines for their health care needs. Natural plants have a very important role in treatment of liver diseases. There are many natural plants in world which have hepatoprotective activity (Gite et al., 2010) like Carissa spinarum (Hegde and Joshi, 2010), Cocculus hirsutus (Thakare et al., 2009), Convolvulus arvensis (Ali et al., 2013), Dodonaea viscosa (Khan et al., 2013), Khamira Gaozaban Ambri Jadwar Ood Saleeb Wala (Akhtar et al., 2013), Ipomoea staphylina (Bag and Mumtaz, 2013), Suaeda fruticosa (Rehman et al., 2013), Trianthema decandra (Balamurugan and Muthusamy,
2008) and Trichodesma sedgwickianum (Saboo et al., 2013) showed hepatoprotective effect.

Pakistan is granted with large number of medicinally important plants and has ancient herbal treatment method. The local communities of different regions of Pakistan have centuries old knowledge about traditional uses of plants occurring in their areas. Several indigenous plants are used to treat liver disorders (Ivvora et al., 1989).

Thymus linearis Benth belongs to the Labiatae family which is one of the largest and most diverse family of medicinal plants. It is mostly used in home remedies. Plant is aromatic, antiseptic, diaphoretic, analgesic, diuretic, carminative and stimulant. It is also used in rheumatism gout and sciatica. The herbal decoction may assist to prevent hair loss (Sharma et al., 2005). It is also given in weak vision, complaints of liver, suppression of urine and mensturation (Qureshi, 2007). 
Hence, this study was undertaken to investigate the hepatoprotective effects of extract on paracetamol and carbon tetrachloride $\left(\mathrm{CCl}_{4}\right)$-induced albino mice hepatic injury.

\section{Material and Methods}

\section{Chemicals}

$\mathrm{CCl}_{4}$ (Merck Darmstadt, Germany), paracetamol (Zenith Pharma Karachi, Pakistan), silymarin, diagnostic kits for the estimation of ALT, AST and ALP (Diasys, Germany) were used. Chemicals and reagents used in these experiments were of analytical grade and prepared in distilled water.

\section{Plant material used}

The selected plant was collected from the mountains of the village Shikiyote; district Gilgit, Gilgit-Baltistan. Plant was identified and authenticated by Dr. Shair Wali, Department of Botany, Karakoram International University, Gilgit-Baltistan. Plant material was shade dried and powdered with a Chinese herbal grinder. The powdered material was stored in well closed cellophane bags at $4^{\circ} \mathrm{C}$ in refrigerator.

\section{Preparation of plant extracts}

The powdered plant was extracted by method of cold maceration. One $\mathrm{kg}$ of plant powder was extracted by using solvents; ether and distilled water (Aghel et al., 2011). For extraction with each solvent, the plant powder was soaked for 72 hours with occasional shaking. It was passed through muslin cloth and then filtered through filter paper. The aqueous and ether extracts were prepared with the help of rotary evaporator.

\section{Animals used}

Adult healthy albino mice (25-30 g) of either sex were used in the study and kept under natural light and dark cycle at a temperature of $28 \pm 4^{\circ} \mathrm{C}$, given a standard pellet diet and water ad libitum.

\section{Hepatoprotective activity against paracetamol-} induced toxicity in mice

After an overnight fasting, mice were divided into seven groups of five animals each. Group 1 was control group which received single dose of 5\% tween 80 daily for 4 days orally and on $3^{\text {rd }}$ day single dose of $40 \%$ sucrose solution. Group 2 was paracetamol group and it received single dose of $5 \%$ tween 80 daily for 4 days orally and on $3^{\text {rd }}$ day single dose of paracetamol suspension ( $250 \mathrm{mg} / 10 \mathrm{~mL}$ water). Group 3 and 4 were treated daily 250 and $500 \mathrm{mg} / \mathrm{kg}$ of ether extract, while Group 5 and 6 received 250 and $500 \mathrm{mg} / \mathrm{kg}$ of aqueous extract of $T$. linearis respectively for 4 days orally and on $3^{\text {rd }}$ day single dose of paracetamol suspension. Group 7 served as silymarin treated which received silymarin for four days and on $3^{\text {rd }}$ day single dose of paracetamol.
Animals were sacrificed on $5^{\text {th }}$ day, and their blood was collected for biochemical study (Maheswari et al., 2008).

Hepatoprotective activity in $\mathrm{CCl}_{4}$-induced toxicity in mice

After an overnight fasting, mice were divided into seven groups of five mice each. Group 1 served as negative control and was treated with normal saline $(0.9 \%)$ for four days. Group 2 was treated with normal saline and $\mathrm{CCl}_{4}$, on $1^{\text {st }}$ and $4^{\text {th }}$ day, and on $2^{\text {nd }}$ and $3^{\text {rd }}$ day respectively. Group 3 and 4 were treated daily 250 and $500 \mathrm{mg} / \mathrm{kg}$ of ether extract, while group 5 and 6 received 250 and $500 \mathrm{mg} / \mathrm{kg}$ of aqueous extract of $T$. linearis respectively for 4 days orally and on the $2^{\text {nd }}$ and $3^{\text {rd }}$ day $\mathrm{CCl}_{4}$ was given half an hour after the administration of extract dose. Group 7 served as silymarin treated and was given $\mathrm{CCl}_{4}$ and silymarin on $1^{\text {st }}$ and $4^{\text {th }}$ day, and on $2^{\text {nd }}$ and $3^{\text {rd }}$ day respectively. Animals were sacrificed on $5^{\text {th }}$ day, and their blood was collected for biochemical tests (Aghel et al., 2011).

\section{Anti-oxidant activity}

Solution of 1-1-diphenyl-2picryl hydrazine (DPPH) was prepared by dissolving $4.3 \mathrm{mg}$ of $\mathrm{DPPH}$ in $3.3 \mathrm{~mL}$ of methanol and covered with aluminum foil to protect from light. $150 \mu \mathrm{L}$ DPPH solution was added to $3 \mathrm{~mL}$ of methanol and its absorbance was measured at $516 \mathrm{~nm}$ as control reading. Different concentrations (10, 20, 40, $60,80,100 \mu \mathrm{g} / \mathrm{mL}$ ) of aqueous and ether extracts of plant were made and the volume was made uniformly to $150 \mu \mathrm{L}$ using methanol. Each of the samples was then further diluted with methanol up to $3 \mathrm{~mL}$ and to each, $150 \mu \mathrm{L}$ DPPH solution was added. After $15 \mathrm{~min}$ absorbance was measured at $516 \mathrm{~nm}$ by using methanol as blank at UV visible spectrometer. The capability to scavenge the DPPH radicals was calculated using the following formula:

DPPH scavenged $(\%)=\left(\mathrm{A}_{\text {control }}-\mathrm{A}_{\text {sample }}\right) / \mathrm{A}_{\text {control }} \times 100$

Where, $\mathrm{A}_{\text {control }}=$ The absorbance of the control reaction mixture and $\mathrm{A}_{\text {sample }}=$ the absorbance of sample at different concentrations (Molyneux, 2004)

\section{Acute toxicity test}

The aim of this experiment was to determine the $\mathrm{LD}_{50}$ of crude extract. Adult healthy mice of either sex, weighing 25-30 g were randomly divided into nine groups of 2 animals each.

Group 1 served as control and received normal saline $10 \mathrm{~mL} / \mathrm{kg}$. Group 2, 3, 4, 5, 6, 7, 8 and 9 were given different doses of aqueous and ether extracts of $T$. linearis in an ascending order i.e.100, 300, 600, $900 \mathrm{mg} /$ $\mathrm{kg}$ respectively. The mortality rate was observed for 24 hours. Since no mortality occurred so another nine groups of mice were taken. They were again treated with various doses of aqueous and ether extracts in an ascending order i.e. 1200, 1500, 1800, $2000 \mathrm{mg} / \mathrm{kg}$ respectively. All the doses were administered by 
Table I

Effects of ether and aqueous extracts of Thymus linearis and silymarin on liver enzymes against paracetamoltreated hepatotoxic albino mice

\begin{tabular}{|c|c|c|c|}
\hline Treatment & ALT (U/L) & AST (U/L) & $\operatorname{ALP}(\mathrm{U} / \mathrm{L})$ \\
\hline Normal control & $37.4 \pm 7.2$ & $30.6 \pm 5.3$ & $74.0 \pm 6.2$ \\
\hline Paracetamol control & $96.4 \pm 9.7$ & $74.2 \pm 7.5$ & $100.2 \pm 6.1$ \\
\hline Ether extract $(250 \mathrm{mg} / \mathrm{kg})+$ Paracetamol & $76.6 \pm 3.2^{\mathrm{a}}$ & $49.8 \pm 3.1^{a}$ & $119.8 \pm 17.1^{\mathrm{a}}$ \\
\hline Ether extract $(500 \mathrm{mg} / \mathrm{kg})+$ Paracetamol & $65.2 \pm 2.2^{a}$ & $41.2 \pm 5.3^{a}$ & $106.4 \pm 3.3^{\mathrm{a}}$ \\
\hline Aqueous extract $(250 \mathrm{mg} / \mathrm{kg})+$ Paracetamol & $82.4 \pm 9.1^{b}$ & $52.0 \pm 2.3^{b}$ & $82.4 \pm 1.7 \mathrm{~b}$ \\
\hline Aqueous extract $(500 \mathrm{mg} / \mathrm{kg})+$ Paracetamol & $73.2 \pm 6.1^{b}$ & $49.2 \pm 3.4^{b}$ & $78.0 \pm 0.8^{b}$ \\
\hline Silymarin + Paracetamol & $64.4 \pm 1.3 c$ & $44.0 \pm 2.4^{c}$ & $69.4 \pm 1.2^{c}$ \\
\hline
\end{tabular}

Table II

Effects of EETLB, AETLB and silymarin on liver enzymes against $\mathrm{CCl}_{4}$ treated hepatotoxic Albino mice albino mice

\begin{tabular}{|c|c|c|c|}
\hline Treatment & $\operatorname{ALT}(\mathrm{U} / \mathrm{L})$ & AST (U/L) & $\operatorname{ALP}(\mathrm{U} / \mathrm{L})$ \\
\hline Normal control & $37.4 \pm 7.2$ & $30.6 \pm 5.1$ & $74.0 \pm 6.2$ \\
\hline $\mathrm{CCl}_{4}$ control & $127.4 \pm 12.8$ & $66.2 \pm 7.8$ & $131.6 \pm 13.6$ \\
\hline Ether extract $(250 \mathrm{mg} / \mathrm{kg})+\mathrm{CCl}_{4}$ & $100 \pm 3.9 \mathrm{a}$ & $51.4 \pm 3.8^{c}$ & $96.2 \pm 1.7^{a}$ \\
\hline Ether extract $(500 \mathrm{mg} / \mathrm{kg})+\mathrm{CCl}_{4}$ & $76.6 \pm 1.7 \mathrm{c}$ & $43.4 \pm 5.2^{c}$ & $92.0 \pm 3.1^{\mathrm{a}}$ \\
\hline Aqueous extract $(250 \mathrm{mg} / \mathrm{kg})+\mathrm{CCl}_{4}$ & $99.4 \pm 5.8^{a}$ & $52.2 \pm 3.8^{a}$ & $111.6 \pm 7.6^{a}$ \\
\hline Aqueous extract $(500 \mathrm{mg} / \mathrm{kg})+\mathrm{CCl}_{4}$ & $65.8 \pm 11.0^{c}$ & $39.4 \pm 3.4^{a}$ & $104.8 \pm 2.5^{b}$ \\
\hline Silymarin $+\mathrm{CCl}_{4}$ & $32.6 \pm 2.3^{c}$ & $34.0 \pm 2.3 c$ & $84.8 \pm 1.9 \mathrm{c}$ \\
\hline
\end{tabular}

intraperitoneal route. The highest dose which did not kill any mice, and the lowest dose which killed only one mice was noted. $\mathrm{LD}_{50}$ was calculated from the mean of these two doses (Shetty et al., 2007).

\section{Preliminary phytochemical analysis}

The aqueous and ether extracts of T. linearis were analyzed for the presence of different phytochemical constituents such as flavonoids, reducing sugars, tannins, phenolic compounds, saponins, alkaloids and cardiac glycosides by using standard methods (Khandelwal, 2006).

\section{Statistical analysis}

The data were expressed as mean \pm standard error of mean (SEM) and analyzed by using t-test. $\mathrm{P}<0.05$ was considered as significant.

\section{Results}

There was a significant increase in the level of liver enzymes in paracetamol-treated group compared to normal control group. Ether extract significantly $(p<0.05)$ decreased the level of liver enzymes in 250 $\mathrm{mg} / \mathrm{kg}$ and $500 \mathrm{mg} / \mathrm{kg}$ extract treated group. Aqueous extract also significantly $(\mathrm{p}<0.01)$ decreased the level of liver enzymes in $250 \mathrm{mg} / \mathrm{kg}$ and $500 \mathrm{mg} / \mathrm{kg}$ treated group. There was highly significant $(p<0.001)$ decrease in the liver enzymes (ALT, AST, ALP) in silymarintreated group compared to paracetamol treated group (Table I).
In extract treated group with the dose of $250 \mathrm{mg} / \mathrm{kg}$ there was a significant $(\mathrm{p}<0.05)$ decrease in liver enzymes and with the dose of $500 \mathrm{mg} / \mathrm{kg}$ there was a significant $(p<0.001),(p<0.05),(p<0.01)$ decrease in the level of ALT, AST and ALP respectively. However, there was highly significant $(p<0.001)$ decrease in the liver enzymes in silymarin-treated group compared to $\mathrm{CCl}_{4}$-treated group (Table II).

In $\mathrm{CCl}_{4}$ treated group there was a significant increase in the level of liver enzymes compared to normal control group. Ether extract with a dose of $250 \mathrm{mg} / \mathrm{kg}$ significantly $(p<0.05),(p<0.001),(p<0.05)$ decreased the level of ALT, AST, ALP respectively. There was a highly significant decrease in the liver enzymes in $500 \mathrm{mg} / \mathrm{kg}$ and silymarin-treated group compared to $\mathrm{CCl}_{4}$-treated group (Table II).

Aqueous extract of $T$. linearis in a concentration of 10 , 20, 40, 60, 80 and $100 \mu \mathrm{g} / \mathrm{mL}$ significantly scavenged 84.0, 88.2, 89.9, 93.4, 94.9, 95\% DPPH free radical respectively. While ether extract significantly $85.7,88.9$, 91.1, 94.7, 95.7, 96.1\% scavenged DPPH free radical in a concentration-dependent manner. Results obtained were comparable with standard anti-oxidant ascorbic acid (Figure 1).

$\mathrm{LD}_{50}$ of ether and aqueous extracts of Thymus linearis was found to be 1050 and $900 \mathrm{mg} / \mathrm{kg}$ in mice respectively.

Preliminary phytochemical analysis revealed the presence of alkaloids, flavonoids. The other secondary metabolites like tannins, saponins, steroids, cardiac gly- 


\begin{tabular}{|lcc|}
\hline \multicolumn{3}{|c|}{ Table III } \\
\hline \multicolumn{3}{|c|}{ Preliminary phytochemical analysis of } \\
Thymus linearis \\
\hline \multicolumn{3}{|c|}{ Aqueous } \\
extract & $\begin{array}{c}\text { Ether } \\
\text { extract }\end{array}$ \\
\hline Tanins & + & + \\
Saponins & - & + \\
Flavanoids & + & + \\
Steroids & + & - \\
Cardiac glycosides & + & + \\
Reducing sugar & + & - \\
Indole alkaloids & + & + \\
Anthraquinone glycosides & - & - \\
Terpenoids & + & + \\
\hline
\end{tabular}

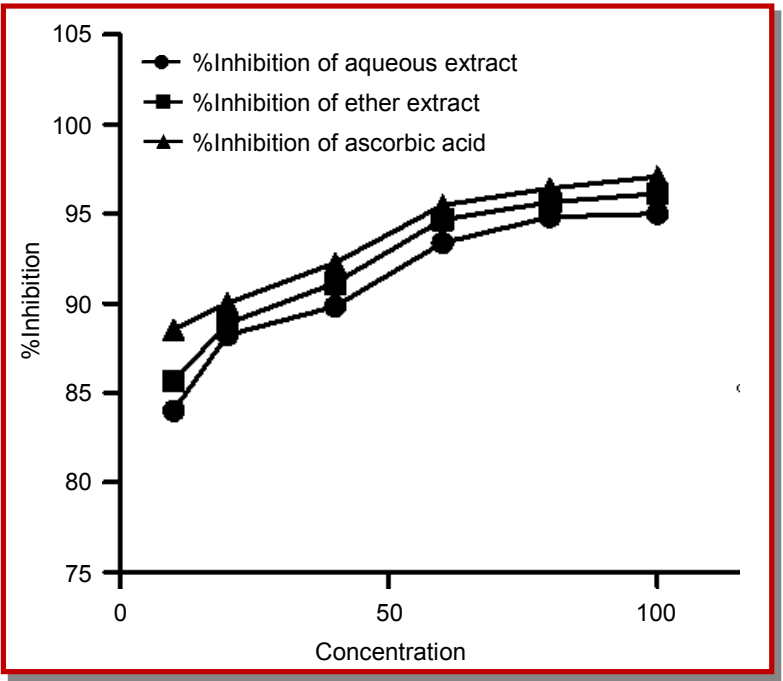

Figure 1: Percent inhibition of ascorbic acid, aqueous and ether extract of Thymus linearis

cosides, and reducing sugar were also present (Table III).

\section{Discussion}

The use of medicinal plants has been increased during the last few decades. However, the use of these medicinal plants into the modern therapy requires their toxicological and pharmacological evaluation on scientific basis. So, the current study was carried out to evaluate the hepatoprotective effect of $T$. linearis in paracetamol- and $\mathrm{CCl}_{4}$-induced hepatotoxic mice. In the present study aqueous and ether extract of the plant showed significant hepatoprotective effect. The results were in agreement with the previous study (Ahsan et al., 2009).

In our current study, the levels of ALT, AST and ALP were increased in paracetamol and treated mice which is in accordance with the previous findings (Mittal et al., 2010). All these enzymes metabolize in liver and damage to the liver causes the leakage of these enzymes into the blood circulation and their level increases (Wakchaure et al., 2011).

Treatment with $T$. linearis extracts restored the elevated values of liver enzymes near to normal level, which is a clear manifestation of antihepatotoxic effect of T. linearis extracts. The hepatoprotective activity of the extracts may be due to their stabilizing effect on plasma membrane as reported earlier by Nadeem et al. (2011). The inhibition of lipid peroxidation by the active constituents of the extracts might also be involved in hepatoprotective effect which is duly supported by the study of Kanchana et al. (2011). The oxidative stress is considered an important cause of liver injury, induced by hepatotoxic agents. The free radicals especially reactive oxygen species (ROS) are involved in hepatic tissue damage. In our study, aqueous and ether extracts demonstrated the significant anti-oxidant activity in $\mathrm{DPPH}$ scavenging assay which is compared with standard anti-oxidant ascorbic acid. The extracts may produce the hepatoprotective effect by neutralizing the effect of free radical species. The results are in complete agreement with the investigation of Pourmorad et al. (2006). Increased protein synthesis, improved lipoprotein metabolism and presence of phytochemical constituents may also be related to the hepatoprotective effect of extracts (Ahsan et al., 2009).

Extracts in a dose of $500 \mathrm{mg} / \mathrm{kg}$ demonstrated more significant effects as compared to $250 \mathrm{mg} / \mathrm{kg}$ dose. So the aqueous and ether extracts produced the hepatoprotective effect in dose-dependent manner. Silymarin is used as standard hepatoprotective agent and has protective effect on hepatocytes (Kshirsagar et al., 2011). Aqueous and ether extracts of $T$. linearis attenuated significantly the decreased level of these enzymes and caused a subsequent recovery towards normalization almost like that of silymarin treatment. This study calls for further activity-oriented fractionation of these extracts to isolate the active principle (s) and elucidate exact mechanism of action.

\section{Conclusion}

The aqueous and ether extract of $T$. linearis have dosedependent hepatoprotective activity and it may be due to the presence of active constituent(s) in the extracts.

\section{Ethical Issue}

The study protocol was approved by the Institutional Animal Ethics Committee (IEC) Faculty of Pharmacy, University of Sargodha (Approval No. 25-A12 IEC UOS). All the experiments performed complied with the rulings of National Research Council (NRC, 1996). 


\section{References}

Aghel N, Kalantari H, Rezazadeh S. Hepatoprotective effect of Ficus carica leaf extract on mice intoxicated with carbon tetrachloride. Irani J Pharm Sci. 2011; 10: 63-68.

Ahsan R, Islam KM, Musaddik A, Haque E. Hepatoprotective activity of methanol extract of some medicinal plants against carbontetrachloride induced toxicity in albino rats. Global J Pharmacol. 2009; 3: 116-22.

Akhtar MS, Asjad HMM, Bashir S, Malik A, Khalid R, Gulzar F, Irshad N. Evaluation of anti-oxidant and hepatoprotective effects of Khamira Gaozaban Ambri Jadwar Ood Saleeb Wala (KGA). Bangladesh J Pharmacol. 2013; 8: 4448.

Akhtar MS, Nadeem M, Rashid HU, Bashir S. Hypoglycemic activity of different fractions of Berberis aristata root-bark in normal and alloxan diabetic rabbits. Can J of App Sci. 2011; 1: 16-28.

Ali M, Qadir MI, Saleem M, Janbaz KH, Gul H, Hussain L, Ahmad B. Hepatoprotective potential of Convolvulus arvensis against paracetamol-induced hepatotoxicity. Bangladesh J Pharmacol. 2013; 8: 300-04.

Bag AK, Mumtaz SMF. Hepatoprotective and nephroprotective activity of hydroalcoholic extract of Ipomoea staphylina leaves. Bangladesh J Pharmacol. 2013; 8: 263-68.

Balamurugan G, Muthusamy P. Observation of the hepatoprotective and anti-oxidant activities of Trianthema decandra Linn. (Vallaisharunnai) roots on carbon tetrachloridetreated rats. Bangladesh J Pharmacol. 2008; 3: 83-89.

Guntupalli M. Hepatoprotective effects of rubiadin, a major constituent of Rubia Cordifolia. J Ethnopharmacol. 2006; 103: 484-90.

Hegde K, Joshi AB. Hepatoprotective and anti-oxidant effect of Carissa spinarumroot extract against $\mathrm{CCl}_{4}$ and paracetamolinduced hepatic damage in rats. Bangladesh J Pharmacol. 2010; 5: 73-76.

Ivorra S, Paya M, Villar A. A review of natural products and plants as potential antidiabetic drugs. J Ethnopharmacol. 1989; 27: 243-75.

Kanchana N, Sadiq AM. Hepatoprotective effect of Plumbago zeylanica on paracetamol-induced liver toxicity in rats. Int J Pharm Pham Sci. 2011; 3: 151-54.

Khandelwal KR. Practical pharmacognosy. 12 $2^{\text {th }}$ ed. Pune, Nirali Prakashan Publishers, 2006, 149-53.

Khan AZ, Mohammad A, Iqbal Z, Anis I, Shah MR, Nadeem S, Rabnawaz M, Shahidullah A, Khan H, Khan I. Molecular docking of viscosine as a new lipoxygenase inhibitor isolated from Dodonaea viscose. Bangladesh J Pharmacol. 2013; 8: 36-39.

Kshirsagar AD, Mohite R, Aggrawal AS, Suralkar UR. Hepatoprotective medicinal plants of Ayurveda: A review. Asian J Pharmaceut Clin Res. 2011; 4: 1-8.
Maheswari C, Maryammal R, Venkatanarayanan S. Hepatoprotective activity of Orhosiphon stamineus on liver damage caused by paracetamol in rats. JJBS. 2008; 1: 105-08.

Mittal DK, Joshi D, Shukla S. Protective effects of Polygonum bistorta (Linn.) and its active principle against acetaminophen-induced toxicity in rats. Asian J Exp Biol Sci. 2010; 1: 951-58.

Modak M, Dixit P, Londhe J, Ghaskadbi S, Devasagayam TPA. Indian herbs and herbal drugs used for the treatment of diabetes. J Clin Biochem Nutr. 2007; 40: 163-73.

Molyneux PH. The use of stable free radical diphenyl picrylhydrazyl (DPPH) for estimating anti-oxidant activity. Songklanakarin J Sci Tech. 2004; 26: 211-19.

Nadeem MPC, Dandiya PC, Pasha M, Imran D, Balani K, Vohora SB. Hepatoprotective activity of Solanum nigrum fruits. Fitoterapia 1997; 68: 245-51.

NRC. Guide for the care and use of laboratory animals. Washington DC, National Academy Press, 1996.

Periasamy M, Pavankumar K, Gangadhar V, Jeeva T, Anandhan R, Sengottuvelu S. Hepatoprotective and antioxidant activity of Euphorbia ligularia against carbon tetrachloride induced hepatotoxicity in Wistar rats. Int J Res Pharm Biomed Sci. 2012; 3: 100-04.

Pourmorad F, Hosseinimehr SJ, Shahabimajd N. Anti-oxidant activity, phenol and flavonoids contents of some selected Iranian medicinal plants. Afr J Biotech. 2006; 5: 42-1145.

Qureshi LR. Ethnobotanical studies of selected medicinal plants of Sudhan Gali and Ganga Chotti Hills, District, Azad Kashmir. Pak J Bot. 2007; 39: 2275-83.

Rajesh MG, Latha MS. Hepatoprotection by Elephatopus scaber Linn in $\mathrm{CCl}_{4}$ induced liver injury. Indian $\mathrm{J}$ Physiol Pharmacol. 2001; 45: 481-86.

Rehman JU, Saqib NU, Akhtar N, Jamshaid M, Asif HM, Sultana S, Rehman RU. Hepatoprotective activity of aqueous-methanolic extract of Suaeda fruticosa in paracetamol-induced hepatotoxicity in rabbits. Bangladesh J Pharmacol. 2013; 8: 378-81.

Saboo SS, Tapadiya G, Farooqui IA, Khadabadi SS. Free radical scavenging, in vivo antioxidant and hepatoprotective activity of folk medicine Trichodesma sedgwickianum. Bangladesh J Pharmacol. 2013; 8: 58-64.

Sharma PK, Lal B. Ethnobotanical notes on some medicinal and aromatic plants of Himachal Pradesh. Indian J Traditional Knowledge. 2005; 4: 424-28.

Shetty A, Shyamjith, Deepa, Alwar, MC. Acute toxicity studies and determination of median lethal dose. Current Sci. 2007; 93: 917-20.

Wakchaure D, Jain D, Singhai AK, SomanI R. Hepatoprotective activity of Symplocos racemosa Roxb. bark extract in carbon tetrachloride induced liver damage in rats. J Ayurveda Integr Med. 2011; 2: 137-43.

\footnotetext{
Author Info

Taseer Ahmad (Principal contact)

i e-mail: drtasir2011@ gmail.com
} 